\title{
Effect of the prenatal action of fulvestrant on the ovaries of the offspring of laboratory mice
}

\author{
Rimma T. Sulaymanova ${ }^{1,2}$ \\ ${ }^{1}$ Bashkir State Medical University, Ufa, Russian Federation \\ ${ }^{2}$ University «REAVIZ», Saint Petersburg, Russian Federation \\ rimma2006@bk.ru
}

\begin{abstract}
Annotation. Relevance. Fulvestrant is used for the treatment of breast cancer in combination with other drugs. The aim of the study was to determine the effect of the prenatal action of fulvestrant on the ovaries of the offspring of laboratory mice. Materials and Methods. The experimental animals were divided into 4 groups: intact, control and 2 experimental, 5 animals in each group. Injections were administered to females after fertilization at the gestational stage $\mathrm{E} 11.5$ once intramuscularly. In the control group $(n=5)$, sterile castor oil was administered at a dose of $0.8 \mathrm{mcg} / \mathrm{kg}$. In the first experimental group $(\mathrm{n}=5)$, an antiestrogen was introduced in the form of an oil solution of fulvestrant $0.08 \mathrm{ml} 0.0005 \%$ at a dose of $20 \mathrm{mcg} / \mathrm{kg}$. In the second group ( $\mathrm{n}=5$ ), an antiestrogen was introduced in the form of an oil solution of fulvestrant $0.4 \mathrm{ml} 0.0005 \%$ at a dose of $100 \mathrm{mcg} / \mathrm{kg}$. Results and Discussion. The study revealed that in the ovaries when the drug was administered at a dose of $20 \mathrm{mcg} / \mathrm{kg}$ (F-20), the number of primordial follicles was reduced. Accordingly, the number of follicles of subsequent generations decreased. With the introduction of the drug fulvestrant $100 \mathrm{mcg} / \mathrm{kg}$ (F-100) on the section of the ovary, sclerosis of the stromal component is observed, accompanied by a rearrangement of the vascular network with signs of atresia and cystic degeneration of the follicular epithelium in the secondary and tertiary follicles, formed cysts are observed in the ovarian parenchyma. Conclusion. The prenatal effect of the drug fulvestrant on the maternal body during pregnancy leads to persistent structural changes in the ovaries of the offspring, manifested in the late stages of ontogenesis, which, in turn, can lead to violations of reproductive function. The depth and scale of these changes are dose-dependent.
\end{abstract}

Keywords: fulvestrant, ovaries, laboratory mice, offspring, prenatal exposure

Author contributions. The author has carried out experimental work, data processing, analysis and interpretation of the results, writing an article.

Conflicts of interest statement. The author declares no conflict of interest.

Received 24.05.2021. Accepted 11.06.2021.

(C) Sulaymanova R.T., 2021

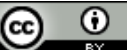

This work is licensed under a Creative Commons Attribution 4.0 International License

https://creativecommons.org/licenses/by/4.0/ 
For citation: Sulaymanova RT. Effect of the prenatal action of fulvestrant on the ovaries of the offspring of laboratory mice. RUDN Journal of Medicine. 2021;25(3):256—262. doi: 10.22363/2313-0245-2021-25-3-256-262

\section{Introduction}

According to the WHO classification, the estrogen drug fulvestrant is a competing antagonist that has a binding, blocking and enhancing degradation on estrogen receptors [1]. Fulvestrant has an antagonistic effect on the estrogen receptor, and also causes an accelerated effect on the estrogen receptors throughout the body [2]. Having a higher affinity for estrogen receptors, having a steroid structure, fulvestrant completely blocks the trophic effect of estradiol on the uterus [3]. Due to its mechanism of action and good tolerability, fulvestrant is recommended to be used in combination with other drugs for the treatment of breast cancer [4]. The prenatal effect of fulvestrant on the reproductive system of the offspring depends on the method of administration (single, fractional, long-term) and the dose (concentration) of administration in the maternal body [5]. In the available scientific, medical and patent literature, the prenatal effects of the drug fulvestrant on the structure of ovarian offspring are few and contradictory. The aim of the study was to study the effect of the prenatal action of fulvestrant on the ovaries of the offspring of laboratory mice.

\section{Materials and methods}

The experimental study was conducted on laboratory mice $(n=20)$, weighing $19-21 \mathrm{~g}$. At the stage of gestation E11.5 after fertilization, the females were divided into 4 groups: intact, control and 2 experimental. Laboratory animals obtained in the nursery of the State Unitary Enterprise DP PSH «Laboratory Animal Nursery», (RB, Chishminsky district), comply with the vivarium condition and animal maintenance RD-APK 3.10.07.02-09 "Methodological recommendations for the maintenance of laboratory animals in vivariums of research institutes and educational institutions», other sanitary standards and requirements of veterinary control and supervision of work with laboratory and experimental animals, license No. 99-04-000097 of 25.01.2005 of the Federal Service for Supervision in the Field of Health and Social Development. The intact group $(n=5)$ did not participate in the experiment. In the control group $(n=5)$, an intramuscular injection of sterile castor oil (MC) at a dose of $0.8 \mathrm{mcg} / \mathrm{kg}$ was performed. In the first experimental group $(n=5)$, an oil solution of fulvestrant in $0.08 \mathrm{ml}$ of $0.0005 \%$ at a dose of $20 \mathrm{mcg} / \mathrm{kg}(\mathrm{F}-20)$ was introduced. In the second experimental group $(n=5)$, an oil solution of fulvestrant $0.4 \mathrm{ml} 0.0005 \%$ at a dose of $100 \mathrm{mcg} / \mathrm{kg}$ (F-100) was introduced. Experimental injections were administered to prenatally pregnant females intramuscularly and once, and the effectiveness of the drug doses was calculated in accordance with the coefficients for recalculating the doses of substances in $\mathrm{mcg} / \mathrm{kg}$ for laboratory mice [6-8].

The offspring (5 animals born from females of each group) were removed from the experiment on the 90th day in the same phase of the estrous cycle - in the diestrus phase [9]. For morphological examination, the right ovary was extracted in accordance with Directive 2010/63/EU of the European Parliament and of the Council of the European Union of 22.09.2010 on the protection of animals for scientific purposes and the recommendations of other international, Russian and institutional regulations in the field of bioethics. All experiments were performed in accordance with the Geneva Convention «Internetional Guiding Principles for Biomedical Involving Animals» (Geneva, 1990), as well as the Helsinki Declaration of the World Medical Association on the Humane Treatment of Animals (revision 2000), The organs were fixed in $10 \%$ neutral buffered formalin for 24 hours, and subjected to standard histological treatment.

A survey microscopy of the morphological analysis of the tissue components of the ovaries of the offspring was performed, morphometric structures were studied: 
the average cross-sectional area, cortical and medullary substances of the ovary, the average diameter of blood vessels, the average number of primordial, primary, secondary, tertiary and atretic follicles, the average number of yellow bodies and luteal cells (Table 1). The study, visualization and morphometry of histological preparations were performed using an inverted biological microscope Axio observer D1, manufactured by Carl Zeiss Microscopy GmbH (Germany) with specialized software for managing settings and capturing images. The work was approved by the Ethics Committee of Bashkir State Medical University.

\section{Results and discussion}

The histological structure of the ovaries of the offspring of laboratory mice as a result of intramuscular single prenatal administration of the drug fulvestrant at a dose of $20 \mathrm{mcg} / \mathrm{kg}$ (F-20) of a pregnant mouse is represented by the following morphometric indicators (Fig. 1, 2, 3, Table 1). The outside of the ovary is covered with a superficial single-layer flat, sometimes cubic epithelium. The protein membrane is thickened, has a homogeneous structure, is weakly vascularized, in the average area of the cortical and medullary substances, changes are not observed in comparison with the intact group, this can be traced in the average area of the cross-section of the ovary.

In the cortical substance, the most characteristic morphological difference is a decrease in the number of primordial follicles entering into growth, while the follicles in subsequent generations (primary, secondary, tertiary) were not affected in comparison with the intact and control groups.

The connective tissue base of the ovarian medulla contains larger blood vessels in average diameter compared to the intact and control groups.

Atretic follicles were detected by the loss of granulosa cells in the follicle cavity, by the detachment of this shell from the internal fluid, the appearance of degeneration in it, and by the disappearance of the shiny shell.

In comparison with the intact group, the average number of atretic follicles in the ovary of the offspring did not change, and a decrease in atretic bodies was observed in the control group.

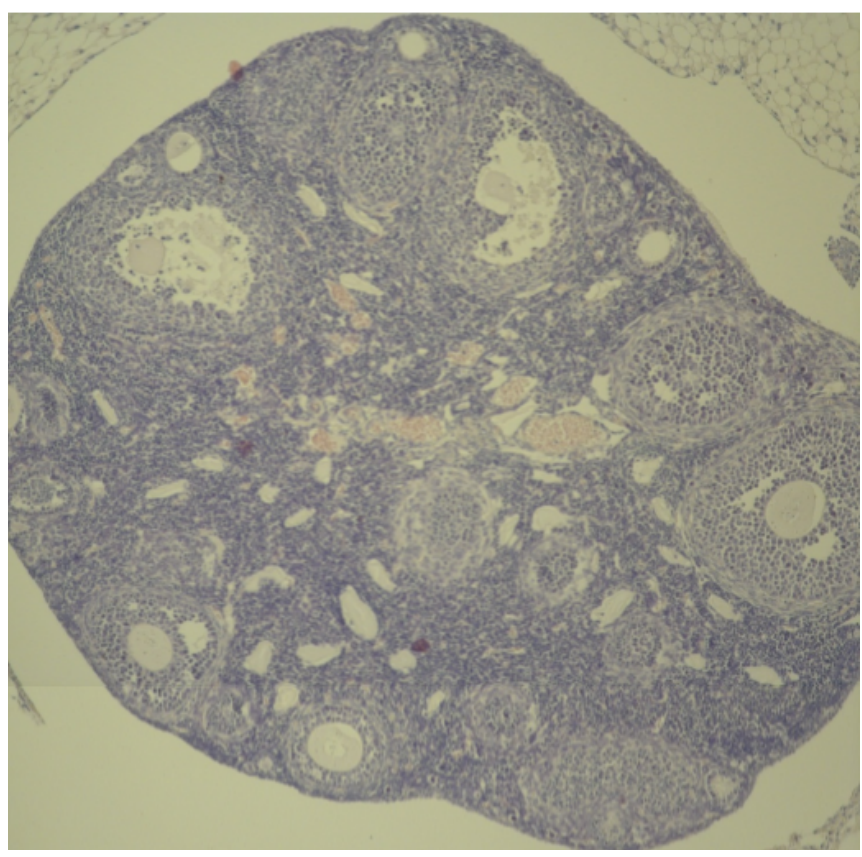

Fig. 1. Microphoto of the ovary preparation of the offspring of an intact laboratory mouse. Stained with hematoxylin-eosin. Magnification x 100

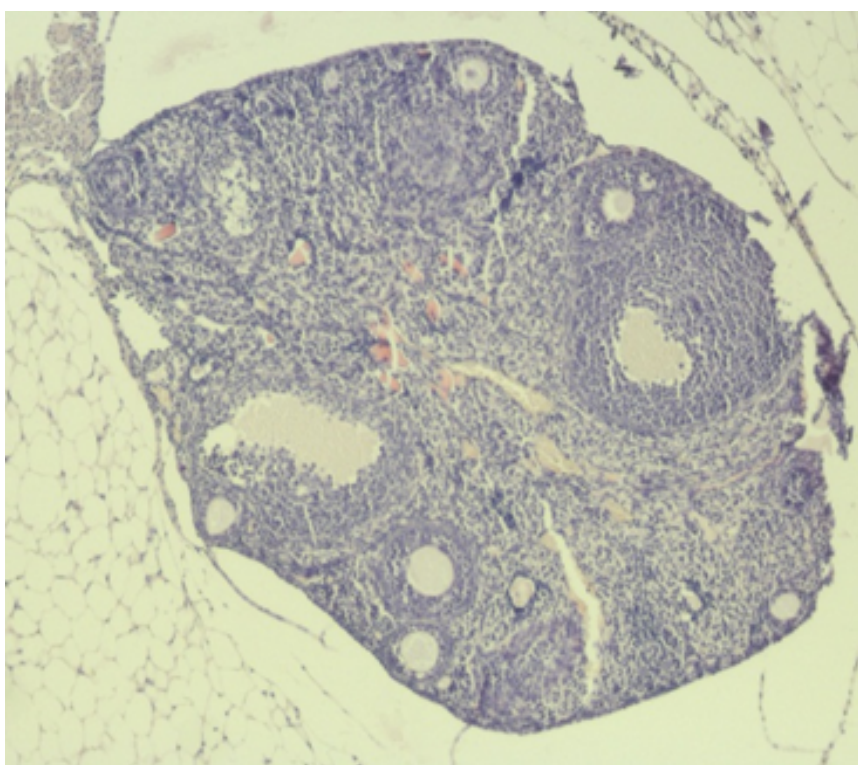

Fig.2. Microphoto of the ovary preparation of the offspring of the control group of animals. Stained with hematoxylin-eosin. Magnification $\times 100$ 


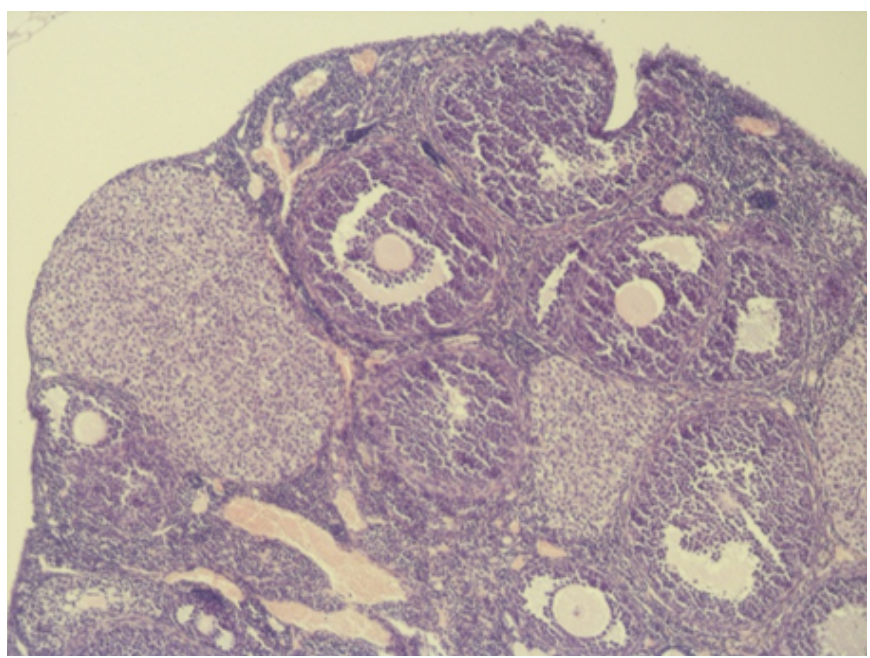

Fig.3. Microphoto of the ovarian preparation of mouse offspring with the introduction of fulvestrant during pregnancy at a dose of $20 \mathrm{mcg} / \mathrm{kg}$. Stained with hematoxylin-eosin. Magnification x 100 .

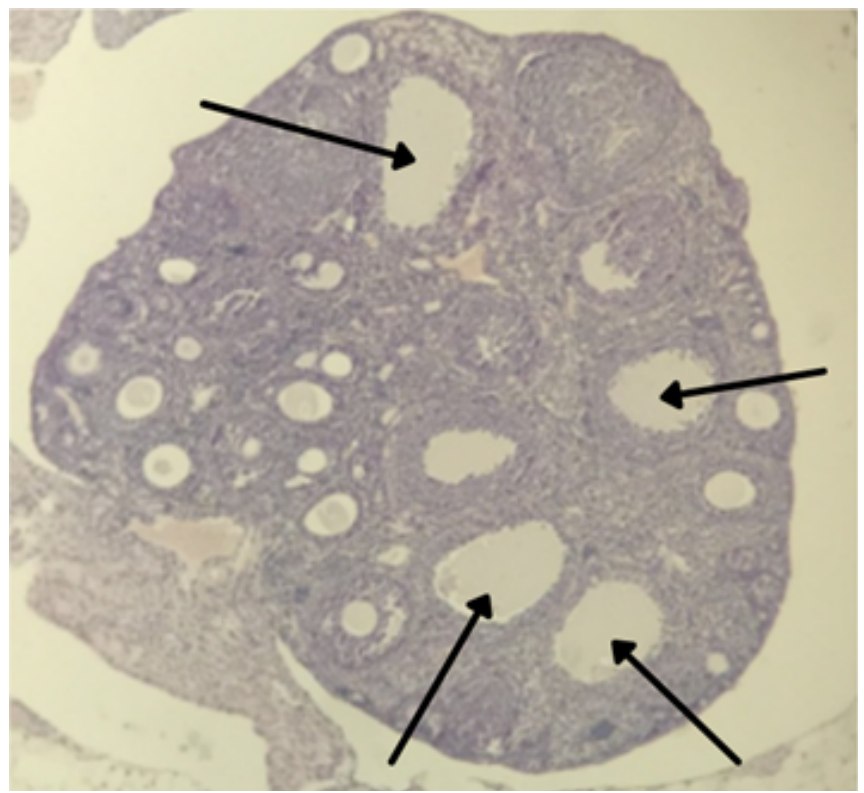

Fig.4. Microphoto of the ovarian preparation of mouse offspring with the introduction of fulvestrant during pregnancy at a dose of $100 \mathrm{mcg} / \mathrm{kg}$, the predominance of cystic altered follicular structures. Stained with hematoxylin-eosin. Magnification $\times 100$.

The yellow bodies are arranged evenly, covered with a connective tissue capsule, from which thin layers of blood vessels are directed to the center. The yellow bodies found have a rounded or oval shape, most of them are in the stage of formation or maturity. The average number of yellow bodies in the ovary of the experimental group did not undergo significant changes compared to the intact group, a decrease in yellow bodies is observed in the control group. There is an increase in the average number of luteal cells in the yellow body of the ovary compared to the intact and control groups.

Studies of the ovarian morphology of the offspring of laboratory mice as a result of intramuscular single prenatal administration of the drug fulvestrant at a dose of $100 \mathrm{mcg} / \mathrm{kg}$, (F-100), of a pregnant mouse are presented by the following structural indicators (Fig. 1, 2, 4, Table 1).

Outside, the single-layer epithelium that covers the outer shell of the ovary has a cubic, sometimes flat cell shape. The protein envelope is compacted and weakly vascularized. In the cortical substance, there is a decrease in the average cross-sectional area, cortical and medullary matter in comparison with the intact group and the control group, while in the control group there is an increase in the average area of the medullary matter.

There is no active folliculogenesis in the ovarian cortex. In the ovarian section, there is a significant decrease in the number of primordial follicles in comparison with the intact and control groups. Single primordial follicles are located under the protein shell. The oocytes of primordial follicles are surrounded by a single layer of flat-shaped follicular cells.

The follicular cells in the primary follicles have a cubic shape and lie in $1-2$ layers. The average number of primary follicles in comparison with the intact group and the control group is increased, this phenomenon is also observed in the average number of secondary follicles. In the secondary follicles, which are larger than the primary ones, an additional shell of the teka is formed. The follicular epithelium becomes multilayered. Tertiary follicles have a more pronounced thecal membrane, consisting of an inner layer and containing interstitial (thecal) cells. Dense fibrous connective tissue is represented by the outer layer of teka. The number of tertiary follicles is reduced in contrast to the intact group. 
In the ovarian parenchyma, there is sclerosis of the stromal component, accompanied by a rearrangement of the vascular network, increased blood supply and an increase in the average diameter of the vessels compared to the intact and control groups.

In the sclerosed ovarian stroma, large antral follicles with signs of incipient degeneration or atresia are found, and a statistically significant increase in atretic follicles is observed. The ovarian stroma reacted to the administration of the drug in the form of a pronounced predominance of cystic changes in the follicles of different levels of development. The number of yellow bodies in the ovary decreases in comparison with the intact group and increases in comparison with the control group, there are no changes in the average number of luteal cells.

Table 1

Morphometric parameters of ovaries of offspring of laboratory mice

\begin{tabular}{|c|c|c|c|c|c|}
\hline 1 & $\begin{array}{l}\text { Average cross-sectional area of the ovary, } \\
\qquad \times 10^{3} \mathrm{MKM}^{2}\end{array}$ & $1443,1 \pm 1069,1$ & $964,5 \pm 167,5^{\star}$ & $1428,1 \pm 1002,8$ & $1122,3 \pm 412,2^{\star}$ \\
\hline 2 & $\begin{array}{l}\text { The average area of the ovarian cortex, } \times 10^{3} \\
\text { MKM }^{2}\end{array}$ & $2637,6 \pm 466,6$ & $862,8 \pm 175,3^{*}$ & $2607,2 \pm 294,9$ & $1273,7 \pm 196,7^{\star}$ \\
\hline 3 & $\begin{array}{l}\text { The average area of the ovarian medulla, } \\
\qquad \times 10^{3} \mathrm{MKM}^{2}\end{array}$ & $188,2 \pm 93,3$ & $101,7 \pm 10,4^{\star}$ & $200,0 \pm 78,1 *$ & $73,1 \pm 22,6^{*}$ \\
\hline 5 & $\begin{array}{l}\text { Average number of primordial follicles in the } \\
\text { ovary }\end{array}$ & $37,8 \pm 3,5$ & $8,2 \pm 3,7^{\star}$ & $7,0 \pm 2,3^{*}$ & $11,0 \pm 1,9 *$ \\
\hline 6 & $\begin{array}{l}\text { Average number of primary follicles in the } \\
\text { ovary }\end{array}$ & $6,2 \pm 1,6$ & $4,6 \pm 1,5^{\star}$ & $13,8 \pm 5,2^{\star}$ & $7,6 \pm 2,4^{*}$ \\
\hline 7 & $\begin{array}{l}\text { Average number of secondary follicles in the } \\
\text { ovary }\end{array}$ & $6,6 \pm 1,5$ & $6,6 \pm 1,5$ & $12,2 \pm 4,7 *$ & $10,0 \pm 2,7^{*}$ \\
\hline 9 & $\begin{array}{l}\text { Average number of atretic follicles in the } \\
\text { ovary }\end{array}$ & $4,2 \pm 1,3$ & $3,2 \pm 1,3^{*}$ & $4,6 \pm 1,1$ & $7,4 \pm 1,8^{*}$ \\
\hline 10 & Average number of yellow bodies in the ovary & $4,2 \pm 0,8$ & $1,6 \pm 1,1^{*}$ & $4,8 \pm 1,3$ & $3,2 \pm 1,3^{*}$ \\
\hline 11 & $\begin{array}{c}\text { Average number of luteal cells in the ovarian } \\
\text { corpus luteum }\end{array}$ & $436 \pm 352$ & $465,8 \pm 64,7$ & $560 \pm 422^{\star}$ & $439 \pm 204,7$ \\
\hline
\end{tabular}

*Marked effects are significant at $p \leq 0,05000$

Thus, the experimental analysis makes it possible to conclude that in the ovaries of the offspring of laboratory mice, under the influence of different doses of fulvestrant, morphological rearrangements of the cortical and cerebral substances of the ovary of the offspring are observed. In the ovaries of the experimental groups, when the drug was administered at a dose of $20 \mathrm{mcg} /$ $\mathrm{kg}$ (F-20), the number of primordial follicles that begin to grow was reduced. Accordingly, the number of follicles of subsequent generations decreased. With the introduction of the drug fulvestrant $100 \mathrm{mcg} / \mathrm{kg}$
(F-100) on the section of the ovary, sclerosis of the stromal component is observed, accompanied by a rearrangement of the vascular network with signs of atresia and cystic degeneration of the follicular epithelium in the secondary and tertiary follicles, formed cysts are observed.

\section{Conclusion}

1. The prenatal effect of the drug fulvestrant on the maternal body during pregnancy leads to persistent 
structural changes in the ovaries of the offspring, manifested in the late stages of ontogenesis, which, in turn, can lead to violations of reproductive function.

2. The depth and scale of these changes vary from the morphological to the molecular level, are dosedependent.

3. Reproductive technologies with hormonal support of pregnancy and the use of hormonal drugs of the estrogen series can provoke structural and functional disorders of the ovaries in female offspring. However, the dose dependence of such exposure may allow avoiding such negative effects.

\section{References}

1. The use of stems in the selection of International Nonproprietary Names (INN) for pharmaceutical substances. Geneva: World Health Organization, 2018.

2. Blancas I, Olier C, Conde V et al. Real-world data of fulvestrant as first-line treatment of postmenopausal women with estrogen receptorpositive metastatic breast cancer. Sci Rep. 2021;11(1):4274. doi: 10.1038/ s41598-021-83622-1
3. Semiglazov VF, Dashjan GA, Semiglazov VV. Endocrinotherapy of Breast Cancer: Overriding Resistance. Effective Pharmacotherapy. Oncology, Hematology, Radiology. 2015;1(10):32-43.

4. Slamon DJ, Neven P, Chia S et al. Overall Survival with Ribociclib plus Fulvestrant in Advanced Breast Cancer. N. Ingl. J. Med. 2020;382(6):514-524. doi: 10.1056/NEJMoa1911149

5. Yusupova LR, Sulaymanova RT, Khayrullin RM et al. Somatometric and behavioral characteristics of the mice offspring in early postnatal development which was prenatally treatment with fulvestrant. The $6^{\text {th }}$ international symposium of clinical and applied anatomy. Malinska, KRK island, Rijeka, Croatia. 2014;85.

6. Habriev RU. Guidelines for the experimental study of new pharmacological substances. Medicine. 2005;49—51.

7. Gus'kova TA. Preclinical toxicological study of drugs as a guarantee of the safety of their clinical trials. Russian medical news. 2010;14;1:91-93.

8. Sulaimanova RT, Murzabaev KhKh, Rakhmatullina IR, Khairullin RM, Sulaimanova LI, Sharafutdinova KI, Arslanbekova RR. A method for modeling the pro-carcinogenic effect of ovary fulvestrant in female offspring in laboratory mice. Patent for invention No. 2722988 dated 06/05/2020

9. Cora MC, Kooistra L, Travlos G. Vaginal Cytology of the Laboratory Rat and Mouse: Review and Criteria for the Staging of the Estrous Cycle Using Stained Vaginal Smears. Toxicologic Pathology. 2015;43(6):776_-793. doi: 10.1177/0192623315570339

\title{
Влияние пренатального действия фулвестранта на яичники потомства лабораторных мышей
}

\author{
Р.Т. Сулайманова ${ }^{1,2}$ \\ ${ }^{1}$ Башкирский государственный медицинский университет, г. Уфа, Российская Федерация \\ ${ }^{2}$ Университет «Реавиз», г. Санкт-Петербург, Российская Федерация \\ rimma2006@bk.ru
}

\begin{abstract}
Аннотация. Актуальность. Фулвестрант используется для лечения рака груди в комплексной терапии. Целью исследования было определение влияния пренатального действия фулвестранта на яичники потомства лабораторных мышей. Материалы и методы. Экспериментальные животные были разделены на 4 группы: интактную, контрольную и 2 опытные, по 5 животных в группе. Самкам после оплодотворения на сроке беременности Е11,5 инъекции вводили внутримышечно однократно. В контрольной группе $(\mathrm{n}=5)$ стерильное касторовое масло вводили в дозе 0,8 мкг/кг. В первой опытной группе $(\mathrm{n}=5)$ антиэстроген вводили в виде масляного раствора фулвестранта 0,08 мл 0,0005 \% в дозе 20 мкг/кг. Во второй группе $(\mathrm{n}=5)$ вводили антиэстроген в виде масляного раствора фулвестранта 0,4 мл 0,0005 \% в дозе 100 мкг/кг. Результаты и обсуждение. Исследование показало, что в яичниках при введении препарата в дозе 20 мкг/кг количество примордиальных фолликулов уменьшалось. Соответственно уменьшилось количество фолликулов последующих поколений. При введении препарата фулвестранта 100 мкг/кг на срезе яичника наблюдается склерозирование стромального компонента, сопровождающееся перестройкой сосудистой сети с признаками атрезии и кистозного перерождения фолликулярного эпителия во вторичных и третичных фолликулах, в паренхиме яичника наблюдаются сформированные кисты. Выводы. Внутриутробное действие препарата фулвестрант на организм матери при беременности приводит к
\end{abstract}


стойким структурным изменениям в яичниках потомства, проявляющимся на поздних этапах онтогенеза, что, в свою очередь, может привести к нарушениям репродуктивной функции. Глубина и масштаб этих изменений зависят от дозы.

Ключевые слова: фулвестрант, яичники, лабораторные мыши, потомство, пренатальное введение

Вклад авторов. Автором осуществлена экспериментальная работа, обработка данных, анализ и интерпретация результатов, написание статьи.

Информация о конфликте интересов. Автор заявляет об отсутствии конфликта интересов.

Поступила 24. 05. 2021. Принята 11. 06. 2021.

Для цитирования: Sulaymanova R.T. Effect of the prenatal action of fulvestrant on the ovaries of the offspring of laboratory mice // Вестник Российского университета дружбы народов. Серия: Медицина. 2021. Т. 25. № 3. С. 256 -262. doi: 10.22363/2313-0245-2021-25-3-256-262

Corresponding author: Sulaimanova Rimma Tagirovna — PhD, Associate Professor of the Department of Histology of the Bashkir State Medical University and Associate Professor of the Department of Morphology and Pathology of the REAVIZ University. 199098, St. Petersburg, st. Kalinina, 8, building 2, Russian Federation. E-mail: rimma2006@bk.ru Sulaimanova R.T. ORCID 0000-0002-1658-9054

Ответственный за переписку: Сулайманова Римма Тагировна — к. б.н., доцент кафедры гистологии Башкирского государственного медицинского университета и доцент кафедры морфологии и патологии Университета «Реавиз». Российская Федерация, 199098, г. Санкт-Петербург, ул. Калинина, д. 8, к. 2. E-mail: rimma2006@bk.ru Сулайманова P.T. SPIN - код 4933-2131; ORCID 0000-0002-1658-9054 